\title{
An update on irreversible electroporation of liver tumours
}

\author{
Enoch SL Yeung, Max WY Chung, Keedon Wong, Clement YK Wong, Enoch CT So, Albert CY Chan *
}

\section{A B S T R A C T}

Objective: To investigate the clinical efficacy and safety of irreversible electroporation for ablation of liver tumour in humans.

Data sources: The PubMed and MEDLINE databases were systematically searched.

Study selection: Clinical research published in English in the last 10 years until October 2013 that address clinical issues related to irreversible electroporation of human liver tumours were selected. "Liver tumour", "local ablative therapy", and "irreversible electroporation" were used as the search terms.

Data extraction and synthesis: The data extracted for this review was analysed by the authors, with a focus on the clinical efficacy and the safety of irreversible electroporation. The complete response rates look promising, ranging from $72 \%$ to $100 \%$, except in one study in a subgroup of liver tumours in which the complete response rate was only $50 \%$ that was likely due to the inclusion of larger-size tumours. In one study, the local recurrence rate at

This article was published on 6 Jun 2014 at www.hkmj.org.
12 months was approximately $40 \%$. As for the safety of irreversible electroporation, there were only a few reported complications (cardiac arrhythmia, pneumothorax, and electrolyte disturbance) that were mostly transient and not serious. There was no reported mortality related to the use of irreversible electroporation.

Conclusion: Irreversible electroporation is a potentially effective liver tumour ablative therapy that gives rise to only mild and transient side-effects. Further studies with better patient selection criteria and longer follow-up are needed to clarify its role as a first-line liver tumour treatment modality.

\section{Hong Kong Med J 2014;20:313-6}

DOI: $10.12809 / \mathrm{hkmj} 134190$

ESL Yeung, BDS, MB, BS

MWY Chung, MB, BS

$\mathrm{K}$ Wong, $\mathrm{MB}, \mathrm{BS}$

CYK Wong, $\mathrm{MB}, \mathrm{BS}$

ECT So, BEng (UNSW), MB, BS

ACY Chan *, FCSHK, FHKAM (Surgery)

Department of Surgery, Queen Mary Hospital, The University of Hong Kong, Pokfulam, Hong Kong

* Corresponding author: acchan@hku.hk

\section{Introduction}

Local ablative therapies are frequently employed for the treatment of primary and secondary malignancies in the liver. Common choices include radiofrequency and microwave ablation. These treatment modalities, however, may cause thermal injury to major bile ducts within periductal tumours. In addition, the efficacy of thermal ablative therapy is often undermined by the heat sink effect, whereby the delivered thermal energy is dissipated via a continuous high blood flow in nearby major portal pedicles and hepatic veins. Recently, the use of irreversible electroporation (IRE) has been introduced into clinical practice. The aim of this article was to provide an updated review of the latest developments of this new technology in the management of liver tumours.

\section{Methods}

A search on the medical literature was performed to identify the relevant studies and reviews regarding the use of IRE as a treatment for primary liver neoplasm. Both PubMed and MEDLINE databases were searched for clinical studies published in English in the last 10 years (until October 2013) that involved the use of IRE for liver tumours. Key words used for the literature search were: "liver tumour", "local ablative therapy", and "irreversible electroporation".

\section{Mechanism and history of electroporation}

Electroporation utilises electrical fields to induce changes to plasma membrane permeability. More specifically, multiple rapid direct current electrical pulses are applied to the tissue of interest. These electrical pulses induce nano-scale pores within the phospholipid bilayer, thus changing cell permeability. ${ }^{1}$ There are two types: reversible electroporation (RE) and IRE.

As the name suggests, tissues subjected to $\mathrm{RE}$ remain viable after the procedure. The lesser electrical strength and duration of the applied pulses during the procedure allow pores in the membrane to spontaneously seal by themselves. Researchers 


\section{醫治肝腫瘤的不可逆轉電穿孔技術的最新進展} 楊思朗、鍾永賢、黃基定、黃彥淇、䔡智德、陳智仁

目的：探討針對人類肝腫瘤消融不可逆轉電穿孔技術的臨床療效和安 全性。

資料來源：有系統地搜查在PubMed和MEDLINE數據庫中的有關資 料。

研究選取：選取過去十年直至2013年10月前發表有關人類肝腫瘤不 可逆轉電穿孔技術的臨床研究的英文文獻。用以搜索文獻的關鍵詞 為「肝腫瘤」(liver tumour) 、「局部消融法」（local ablative therapy）和 $\ulcorner$ 不可逆轉的電穿孔術」（irreversible electroporation）。

資料提取及綜合：由作者分析選取的資料, 重點針對不可逆轉電穿孔 技術的臨床療效和安全性。經不可逆轉電穿孔技術治理肝腫瘤的完全 緩解率介乎 $72 \%$ 至 $100 \%$, 結果令人滿意。只有一項研究的其中一個 病人小組, 可能由於腫瘤較大的關係, 其完全緩解率只有 $50 \%$ 。另一 項研究中, 術後 12 個月的局部復發率約為 $40 \%$ 。安全性方面, 有關不 可逆轉電穿孔的併發症報導 ( 心律失常、氣胸、電解質紊亂) 只有少 數, 但大多是短暫的, 並不嚴重。沒有與使用不可逆轉電穿孔技術的 死亡報告。

結論：不可逆轉電穿孔是一種潛在有效的肝腫瘤消融治療技術, 只會 產生輕微和短暫的副作用。須使用更佳的標準選擇合適病人和長期隨 訪作進一步研究 exploited this unique effect of a transient increase in cell permeability to enable foreign materials that were previously deemed impermeable to pass through the phospholipid bilayer. A prominent example would be electrochemotherapy. Since the 1990s, multiple human clinical trials ${ }^{2-4}$ have shown that RE applied for this purpose enhances the delivery of chemotherapy (eg bleomycin) to the desired tissue (eg skin cancer, breast cancer).

By contrast, IRE relies on delivering electrical pulses whose strength and/or duration exceeds the threshold of spontaneous cell membrane repair. The permanent permeability of the cell membrane that they induce disrupts the homeostasis of the cells, leading to cell death. Interestingly, this technique was largely ignored by the medical community until 2005, when Davalos et $\mathrm{al}^{5}$ proved its theoretical basis via a mathematical analysis. This predicted that "irreversible electroporation can ablate substantial volumes of tissue, comparable to those achieved with other ablation techniques, without causing any detrimental thermal effects and without the need of adjuvant drugs."

Rubinsky et $\mathrm{al}^{6}$ performed the first experimental IRE in 2007 by performing 35 ablations on 14 swine livers. Interestingly, all animals survived till the electrical pulse applications ceased, but reversible chemical paralysis was necessary to prevent unwanted muscular contractions during the procedure. Histologically there was haemorrhagic necrosis of the liver, but preservation of the vessels and bile ducts within the zones of ablation. ${ }^{7}$
Since then, many other animal studies have been performed in various organs and tissues, including liver, prostate, pancreas, small bowel, kidney, carotid artery, atrial appendages, and lung. The results were encouraging, in that IRE conferred three key advantages in all of these studies:

(1) It was effective in ablating tissues of interest, including tumours.

(2) It lacked the heat-sink effect. Traditional thermal ablation relied on tissue temperature reaching a certain threshold $\left(60^{\circ} \mathrm{C}\right)$ in order to induce cell death. Cells near the large vessels were therefore prone to the continuously cooling effect from the flowing fluids within the vessels. This leads to incomplete necrosis, making local recurrence of tumours more likely. ${ }^{1}$

(3) It was capable of preserving critical structures (blood vessels, bile ducts, urethra, and nerves) within the zone of ablation. Maor et $\mathrm{al}^{8}$ performed an experiment by applying IRE directly onto the carotid arteries of six rats. All rats survived with no apparent sideeffects. Carotid arteries remained intact with no evidence of aneurysm, thrombus, or necrosis 28 days later. Histologically, there was a statistically significant decrease in mean vascular smooth muscle cell density $(24 \pm 11$ vs $139 \pm 14$; $\mathrm{P}<0.001)$ but with no apparent damage to extracellular matrix components and structure. This may explain why critical structures appear to be preserved with this new technology.

\section{Clinical efficacy of irreversible electroporation on human liver tumours}

To date, four published case series ${ }^{9-12}$ have evaluated the safety and efficacy of IRE on human liver tumours. All of them adopted the NanoKnife system (AngioDynamics, New York, US), which consists of a footswitch, a control panel with a screen and a cardiac synchroniser, and a direct current generator connected with unipolar or bipolar needle electrodes. The number and placement of electrodes are determined by the size of the target tumour. The current, the applied voltage, and duration of ablation can be varied according to tumour characteristics. The procedure can be performed via percutaneous, laparoscopic, or open surgical approaches. ${ }^{9-11}$

The Table ${ }^{9-12}$ illustrates the efficacy and postoperative outcomes after IRE in various case series. The complete response rate ranged from $72 \%$ to $100 \%,{ }^{9-12}$ except in Thomson et al's study ${ }^{9}$ in which the complete response rate was only $50 \%$ for colorectal liver metastasis. That study also demonstrated lack of significant tumour response when the size of the liver metastatic lesion was larger 
TABLE. Clinical efficacy of irreversible electroporation for liver tumours

\begin{tabular}{|c|c|c|c|c|c|c|c|}
\hline Study & Year & $\begin{array}{c}\text { No. of } \\
\text { patients }\end{array}$ & $\begin{array}{l}\text { Mean tumour size } \\
\text { (range) [cm] }\end{array}$ & $\begin{array}{c}\text { Complete ablation } \\
\text { rate }(\%)\end{array}$ & $\begin{array}{c}\text { Morbidity rate } \\
(\%)\end{array}$ & $\begin{array}{l}\text { Follow-up } \\
\text { (months) }\end{array}$ & $\begin{array}{l}\text { Recurrence } \\
\text { rate (\%) }\end{array}$ \\
\hline Thomson et al ${ }^{9}$ & 2011 & 38 & $(1.0-5.0)$ & $\begin{array}{l}83.3 \text { (HCC) } \\
50.0 \text { (CRM) }\end{array}$ & 14.5 & N/A & N/A \\
\hline Cannon et al ${ }^{10}$ & 2013 & 44 & $(2.1-2.7)$ & 100 & 10 (90 Days) & N/A & 40.5 (1 Year) \\
\hline Kingham et al ${ }^{11}$ & 2012 & 28 & $1(0.5-5.0)$ & $\mathrm{N} / \mathrm{A}$ & 3 & 6 & 5.7 (6 Months) \\
\hline Cheung et $\mathrm{al}^{12}$ & 2013 & 11 & $2.4(1.0-6.1)$ & 72 & 36.3 & 18 & 0 \\
\hline
\end{tabular}

Abbreviations: $\mathrm{CRM}=$ colorectal liver metastasis; $\mathrm{HCC}=$ hepatocellular carcinoma; $\mathrm{N} / \mathrm{A}=$ not available

than $5 \mathrm{~cm}$.

In Cannon et al's study, ${ }^{10}$ however, the complete response rates were the same for hepatocellular carcinoma (HCC) and colorectal liver metastasis. The lower complete response rate in Thomson et al's study ${ }^{9}$ could be partially attributed to the inclusion of larger-size tumours and greater use of the percutaneous approach. Consistent with Thomson et al's study, ${ }^{9}$ they also showed a trend towards higher recurrence rates for tumours exceeding $4 \mathrm{~cm}$ in diameter.

The longest follow-up among these studies was 12 months, which was in Cannon et al's study, ${ }^{10}$ by which time the local recurrence rate was about $40 \%$ for both HCC and colorectal liver metastases. To date, no randomised controlled trial comparing the efficacy of IRE and other ablation modalities has been published. The latest quoted figures for recurrence rates are approximately $2 \%$ to $15 \% 2$ years after radiofrequency ablation, and $11 \%$ to $35 \%$ 2 years after percutaneous ethanol injection. ${ }^{13}$

The complete response rate of liver tumour to IRE looked promising, but a $40 \%$ local recurrence rate after 1 year was too high to justify its use as firstline treatment. Moreover, tumour size seems to be an important consideration affecting the outcome. The inclusion of large tumours may have contributed to the high local recurrence rate in Cannon et al's study. ${ }^{10}$ More prospective studies are warranted to define standard selection criteria in order to achieve satisfactory outcomes.

\section{Adverse effects of irreversible electroporation}

Like any other local ablative therapy, IRE is also associated with a few other adverse effects, be they general or procedure-related.

\section{General intra-operative complications}

As with all operations, IRE carries the risk of general anaesthesia ${ }^{9}$ and positional neuropraxia. ${ }^{14}$ In two retrospective studies, such effects occurred in an isolated number of patients but were transient and self-limiting, and resolved without any long-term disability. ${ }^{9,14}$

\section{Specific intra-operative complications}

One of the specific complications related to IRE is unintended injury to other organs and structures during manipulation of the electrodes. One instance of pneumothorax due to direct injury caused by an electrode was reported by Thomson et al. ${ }^{9}$ That pneumothorax resolved spontaneously and did not result in a delayed discharge. The same authors ${ }^{9}$ reported another instance of direct damage by an instrument due to an unplanned tip insertion during an attempt to treat a renal tumour. That particular patient had transient acute hypotension, and subsequent mild hypotension for a further 2 months.

Cardiac arrhythmia is a potential lifethreatening complication associated with IRE, which is presumed due to application of a large current close to the heart, especially for liver tumours situated below the right hemidiaphragm. Thomson et $\mathrm{al}^{9}$ and Ball et $\mathrm{a}^{14}$ reported cases of ventricular bigeminy, ventricular tachycardia, and atrial fibrillation during the procedure, in which a drop in blood pressure was associated with the arrhythmia. Furthermore, IRE has been incorporated with electrocardiographic synchronisation, rendering the possibility of intraoperative arrhythmia less common. Although none of the studies reported mortality due to cardiac arrhythmia, this potentially devastating effect should not be ignored.

In addition to cardiac arrhythmia, discharges from the electrode could cause muscle stimulation. In one case, insufficient muscle relaxant was used, resulting in an upper body contraction similar to what ensues during a grand mal seizure. ${ }^{14}$ Hence, IRE treatment should be performed under general anaesthesia with deep neuromuscular blockade, in order to prevent excessive body movement during treatment.

Since IRE involves the disruption of the cellular membrane, it results in the release of intracellular contents whenever tumour cells are electroporated. Ball et a ${ }^{14}$ reported four instances of hyperkalaemia in 21 patients treated with IRE, but without significant sequelae. Early postoperative arterial blood gas sampling and electrocardiographic monitoring during the procedure may help to prevent the lethal 
consequence of severe hyperkalaemia.

Premature termination of the procedure for technical reasons has also been reported, but detailed explanations were not given. ${ }^{11}$ This complication subjects patients to further IRE treatments, but under more controlled conditions.

\section{Postoperative complications}

The postoperative complications of IRE have been reported in several studies. Postoperative pain was of primary concern for most of the operations. About half of the patients who underwent IRE had some degree of postoperative pain but those treated with either IRE or radiofrequency ablation reported similar pain scores. ${ }^{15}$ Notably, there have been no reported instance of vascular or biliary complications after IRE for periductal tumours or tumours abutting major vessels. This means that for tumours in difficult locations, it is a promising local ablative treatment modality compared with other local ablative therapies. Besides, hitherto there has not been any mortality directly related to IRE. One study reported that the mortality rate at 30 days was $0 \% .{ }^{9}$ However, another study available in abstract form reported one fatality 1 month after the operation, though no other details were provided. ${ }^{16}$ As of 2012, IRE has been performed 158 times in 106 patients with liver tumours, with no attributed mortality. ${ }^{7}$ At the time of writing, a prospective multicentre phase II study on the efficacy and safety profile of the NanoKnife System (AngioDynamics) for early-stage HCC has just been completed and the outcome of this study is eagerly awaited.

\section{Conclusion}

The tumour ablative effect of IRE appears promising. In particular, it seems effective for small tumours $(<3 \mathrm{~cm})$, periductal tumours, and tumours abutting major hepatic vessels, where conventional local ablative treatments for such difficult tumour locations could be risky and less effective.

\section{References}

1. Rubinsky B. Irreversible electroporation in medicine. Technol Cancer Res Treat 2007;6:255-60.

2. Benevento R, Santoriello A, Perna G, Canonico S. Electrochemotherapy of cutaneous metastases from breast cancer in elderly patients: a preliminary report. BMC Surg 2012;12 Suppl 1:S6.

3. Campana LG, Valpione S, Falci C, et al. The activity and safety of electrochemotherapy in persistent chest wall recurrence from breast cancer after mastectomy: a phaseII study. Breast Cancer Res Treat 2012;134:1169-78.

4. Curatolo P, Quaglino P, Marenco F, et al. Electrochemotherapy in the treatment of Kaposi sarcoma cutaneous lesions: a two-center prospective phase II trial. Ann Surg Oncol 2012;19:192-8.

5. Davalos RV, Mir IL, Rubinsky B. Tissue ablation with irreversible electroporation. Ann Biomed Eng 2005;33:22331.

6. Rubinsky B, Onik G, Mikus P. Irreversible electroporation: a new ablation modality-clinical implications. Technol Cancer Res Treat 2007;6:37-48.

7. Charpentier KP. Irreversible electroporation for the ablation of liver tumors: are we there yet? Arch Surg 2012;147:1053-61.

8. Maor E, Ivorra A, Leor J, Rubinsky B. The effect of irreversible electroporation on blood vessels. Technol Cancer Res Treat 2007;6:307-12.

9. Thomson KR, Cheung W, Ellis SJ, et al. Investigation of the safety of irreversible electroporation in humans. J Vasc Interv Radiol 2011;22:611-21.

10. Cannon R, Ellis S, Hayes D, Narayanan G, Martin RC 2nd. Safety and early efficacy of irreversible electroporation for hepatic tumors in proximity to vital structures. J Surg Oncol 2013;107:544-9.

11. Kingham TP, Karkar AM, D’Angelica MI, et al. Ablation of perivascular hepatic malignant tumors with irreversible electroporation. J Am Coll Surg 2012;215:379-87.

12. Cheung W, Kavnoudias H, Roberts S, Szkandera B, Kemp W, Thomson KR. Irreversible electroporation for unresectable hepatocellular carcinoma: initial experience and review of safety and outcomes. Technol Cancer Res Treat 2013;12:233-41.

13. Tiong L, Maddern GJ. Systematic review and meta-analysis of survival and disease recurrence after radiofrequency ablation for hepatocellular carcinoma. Br J Surg 2011;98:1210-24.

14. Ball C, Thomson KR, Kavnoudias H. Irreversible electroporation: a new challenge in "out of operating theater" anesthesia. Anesth Analg 2010;110:1305-9.

15. Narayanan G, Froud T, Lo K, Barbery KJ, Perez-Rojas E, Yrizarry J. Pain analysis in patients with hepatocellular carcinoma: irreversible electroporation versus radiofrequency ablation-initial observations. Cardiovasc Intervent Radiol 2013;36:176-82.

16. Narayanan G, Yrizarry J, Perez-Rojas E, et al. Safety and efficacy of irreversible electroporation in the treatment of primary HCC [abstract]. J Vasc Interv Radiol 2011;22:S63S64. 